\title{
Article \\ Hydrogen Peroxide Activation with Sulfidated Zero-Valent Iron for Synchronous Removal of Cr(VI) and BPA
}

\author{
Haibo Ling ${ }^{1,2}{ }^{,}$Xiaowei Zhu ${ }^{1}$, Ting Zhou ${ }^{1}$, Fan $\mathrm{Su}^{1}{ }^{1}$, Jiangkun $\mathrm{Du}{ }^{1, *}$ and Jianguo Bao ${ }^{1, *}$ (]) \\ 1 School of Environmental Studies, China University of Geosciences, Wuhan 430074, China; \\ zoesling@163.com (H.L.); 1219144@mail.dhu.edu.cn (X.Z.); 18202721355@163.com (T.Z.); \\ sufan0605@126.com (F.S.) \\ 2 Hubei Provincial Academy of Eco-Environmental Sciences, Wuhan 430072, China \\ * Correspondence: dujk@cug.edu.cn (J.D.); bjianguo@cug.edu.cn (J.B.)
}

Citation: Ling, H.; Zhu, X.; Zhou, T.; $\mathrm{Su}, \mathrm{F}$; $\mathrm{Du}, \mathrm{J}$.; Bao, J. Hydrogen Peroxide Activation with Sulfidated Zero-Valent Iron for Synchronous Removal of $\mathrm{Cr}(\mathrm{VI})$ and BPA. Catalysts 2022, 12, 252. https://doi.org/ $10.3390 /$ catal12030252

Academic Editor: Marta Pazos Currás

Received: 29 January 2022

Accepted: 17 February 2022

Published: 23 February 2022

Publisher's Note: MDPI stays neutral with regard to jurisdictional claims in published maps and institutional affiliations.

Copyright: (C) 2022 by the authors. Licensee MDPI, Basel, Switzerland. This article is an open access article distributed under the terms and conditions of the Creative Commons Attribution (CC BY) license (https:// creativecommons.org/licenses/by/ $4.0 /)$

\begin{abstract}
In this work, the synchronous removal of $\mathrm{Cr}(\mathrm{VI})$ and bisphenol A (BPA) in a heterogeneous Fenton process with sulfidated nanoscale zero-valent iron (S-nZVI) as the reductant and catalyst was systematically evaluated. Compared to other systems including S-nZVI or $\mathrm{H}_{2} \mathrm{O}_{2}$ alone, a simultaneous BPA degradation and $\mathrm{Cr}(\mathrm{VI})$ removal could be achieved in the S-nZVI/ $\mathrm{H}_{2} \mathrm{O}_{2}$ system at an optimum $\mathrm{pH}$ of 3 . It was, interestingly, found that $7.8 \%$ of $\mathrm{BPA}$ and $98.2 \%$ of $\mathrm{Cr}(\mathrm{VI})$ were removed within $60 \mathrm{~min}$ in presence of S-nZVI alone, whereas, correspondingly, $98.2 \%$ of BPA and $96.9 \%$ of $\mathrm{Cr}(\mathrm{VI})$ were eliminated in the $\mathrm{S}-\mathrm{nZVI} / \mathrm{H}_{2} \mathrm{O}_{2}$ system. Specifically, humic acid (HA) and $\mathrm{H}_{2} \mathrm{PO}_{4}{ }^{-}$inhibited the deterioration of BPA but posed no significant effect on $\mathrm{Cr}(\mathrm{VI})$ removal. $\mathrm{NO}_{3}{ }^{-}$ had a slight lifting effect on the removal of BPA and $\mathrm{Cr}(\mathrm{VI})$, while $\mathrm{HCO}_{3}{ }^{-}$showed a relatively weak prohibition. Experiments with EPR and radical probe tests also provide direct evidence that hydroxyl radicals was monitored in the S-nZVI/ $\mathrm{H}_{2} \mathrm{O}_{2}$ system, which not only degraded BPA but also inhibited the reduction of $\mathrm{Cr}(\mathrm{VI})$. It could not be ignored that $\mathrm{FeS}$ accelerated $\mathrm{Fe}^{0}$ corrosion to release $\mathrm{Fe}^{2+}$. In, addition, $\mathrm{Fe}^{0}, \mathrm{Fe}^{2+}$ and $\mathrm{S}^{2+}$ could react with $\mathrm{Cr}(\mathrm{VI})$ while the most of produced $\mathrm{Cr}(\mathrm{III})$ was co-precipitated in the form of $\mathrm{Cr}_{\mathrm{x}} \mathrm{Fe}_{1-\mathrm{x}} \mathrm{OOH}$ film. The study confirmed that it was feasible for $\mathrm{S}-\mathrm{nZVI} / \mathrm{H}_{2} \mathrm{O}_{2}$ system to remove synchronously organic pollutants and heavy metal.
\end{abstract}

Keywords: sulfur-modified zero-valent iron; hexavalent chromium; bisphenol A; synchronous removal; Fenton reaction

\section{Introduction}

The co-contamination of heavy metals and refractory organic compounds in wastewater have become an urgent environmental problem nowadays. One typical example is that chromate $(\mathrm{Cr}(\mathrm{VI}))$ is commonly present together with organic pollutants in industrial waste of metal finishing, wood preserving, petroleum refining, and even in contaminated fields. It is well known that $\mathrm{Cr}(\mathrm{VI})$ is acutely toxic, carcinogenic and mutagenic to living organisms. In contrast, $\mathrm{Cr}$ (III) is less toxic and can be easily removed through precipitation [1]. The effective transformation of $\mathrm{Cr}(\mathrm{VI})$ into $\mathrm{Cr}(\mathrm{III})$ is a preferred method for reducing contamination. However, the reduction of $\mathrm{Cr}(\mathrm{VI})$ and the oxidation of organic pollutants seems theoretically contradictory, making this kind of wastewater difficult to treat [2,3]. Thus, efficient and simultaneous removal of $\mathrm{Cr}(\mathrm{VI})$ and organic pollutants is of great significance for water remediation.

Nanoscale zero-valent iron (nZVI) is a versatile material with high reductive capacity $\left(\mathrm{E}^{0}=-0.44 \mathrm{~V}\right)$. Due to this strong reductivity, nZVI has shown attractive potential in the ex/in situ transformation of $\mathrm{Cr}(\mathrm{VI})$ to the less toxic $\mathrm{Cr}$ (III) [4]. Ferrous and ferric ions, as corrosion products of nZVI, would be sacrificed to precipitate with $\mathrm{Cr}$ (III) to form insoluble minerals, making nZVI a promising material for $\mathrm{Cr}(\mathrm{VI})$-bearing wastewater treatment. In addition, the Fenton or Fenton-like reactions are attractive for the removal of recalcitrant contaminants from aqueous solutions via the generation of powerful radicals 
(such as $\cdot \mathrm{OH}$ and $\mathrm{SO}_{4} \cdot{ }^{-}$) from the disintegration of oxidants (such as $\mathrm{H}_{2} \mathrm{O}_{2}$ and persulfate) with $\mathrm{Fe}^{2+}$ oxidized to $\mathrm{Fe}^{3+}$, as per Equations (1) and (2) [5]. Typically, iron acts as the catalyst to activate $\mathrm{H}_{2} \mathrm{O}_{2}$ or persulfate (PS, $\mathrm{S}_{2} \mathrm{O}_{8}{ }^{2-}$ ) to generate into radicals, which exhibit strong oxidizing capability and are capable of degrading most of the organic pollutants to $\mathrm{CO}_{2}, \mathrm{H}_{2} \mathrm{O}$, or intermediate products such as organic acids with a series of rapid chain reactions [6]. In particular, the dissolved $\mathrm{Fe}^{2+}$ is essential for radical production, and nZVI is widely used as a source of in situ $\mathrm{Fe}^{2+}$ precursor in heterogeneous Fenton-like systems [7,8]. Compared to the homogeneous Fenton reaction, the nZVI-Fenton reaction can run in a wider $\mathrm{pH}$ range because of the fast circulation of $\mathrm{Fe}^{2+} / \mathrm{Fe}^{3+}$ on the $\mathrm{Fe}^{0}$ surface $[9,10]$. With these advantages, the nZVI-based Fenton-like reaction is expected to be an efficient means of wastewater purification.

$$
\begin{gathered}
\mathrm{Fe}^{2+}+\mathrm{H}_{2} \mathrm{O}_{2} \rightarrow \mathrm{Fe}^{3+}+\mathrm{OH}^{-}+\cdot \mathrm{OH} \\
\mathrm{Fe}^{2+}+\mathrm{S}_{2} \mathrm{O}_{8}{ }^{2-} \rightarrow \mathrm{Fe}^{3+}+\mathrm{SO}_{4}{ }^{2-}+\mathrm{SO}_{4} \cdot{ }^{-}
\end{gathered}
$$

In a typical Fenton-like process with nZVI, the reducing capacity of $\mathrm{Fe}^{0}$ was used to activate $\mathrm{H}_{2} \mathrm{O}_{2}$ or persulfate with the formation of $\cdot \mathrm{OH}$ or $\mathrm{SO}_{4} \cdot{ }^{-}$for the oxidation of organic pollutants. In this sense, most studies have only focused on the oxidation of organic pollutants, ignoring cases of co-contamination. In fact, nZVI-based Fenton-like systems have the potential to remove both heavy metals and organic pollutants in a single system [11,12]. Yin et al. studied the removal of coexisting $\mathrm{Cr}(\mathrm{VI})$ and 4-chlorophenol by reducing $\mathrm{Cr}(\mathrm{VI})$ in a first step with subsequent $\mathrm{H}_{2} \mathrm{O}_{2}$ oxidation. They found that $100 \%$ of $\mathrm{Cr}(\mathrm{VI})$ could be reduced by nZVI within $20 \mathrm{~min}$, and the subsequent addition of $\mathrm{H}_{2} \mathrm{O}_{2}$ initiated a Fenton reaction for 4-CP degradation [13]. Yang et al. found that the total dissolved copper ( $\mathrm{TCu}$ ) and methylene blue (MB) could be removed together in the $\mathrm{ZVI} / \mathrm{H}_{2} \mathrm{O}_{2}$ system [14]. In addition to the $\mathrm{nZVI} / \mathrm{H}_{2} \mathrm{O}_{2}$ system, the simultaneous removal of phenol and $\mathrm{Cr}(\mathrm{VI})$ could be achieved using a system containing bentonite-supported nZVI (B-nZVI) and persulfate, as reported by Diao et al. [15]. A positive increase in dissolved $\mathrm{Fe}^{2+}$ was found throughout persulfate decomposition, and $\mathrm{SO}_{4} \cdot{ }^{-}$was identified as acting toward phenol degradation, while B-nZVI was responsible for $\mathrm{Cr}(\mathrm{VI})$ [16]. However, the previous studies ignored the interaction effect between $\mathrm{Cr}(\mathrm{VI})$ and organic pollutants, and the efficiency and mechanism of their simultaneous removal in the nZVI/ $\mathrm{H}_{2} \mathrm{O}_{2}$ Fenton-like system are still unclear.

In this study, the synchronous removal of $\mathrm{Cr}(\mathrm{VI})$ and bisphenol $\mathrm{A}(\mathrm{BPA})$ was evaluated in both $\mathrm{H}_{2} \mathrm{O}_{2}$ and persulfate oxidation systems. A sulfidated nanoscale zero-valent iron (S-nZVI) was chosen as the activator of the reaction system, because it has been reported to show significantly better efficiency with respect to $\mathrm{Cr}(\mathrm{VI})$ removal [17]. To elucidate the interaction effects between $\mathrm{Cr}(\mathrm{VI})$ and $\mathrm{BPA}$, the effect of $\mathrm{pH}, \mathrm{H}_{2} \mathrm{O}_{2}$ and catalyst dosage were investigated. The possible mechanism of pollutant elimination was further investigated by radical analysis and material characterization.

\section{Materials and Methods}

All chemicals, including ferrous sulfate $\left(\mathrm{FeSO}_{4} \cdot 7 \mathrm{H}_{2} \mathrm{O}\right)$, sodium sulfide $\left(\mathrm{Na}_{2} \mathrm{~S} \cdot 9 \mathrm{H}_{2} \mathrm{O}\right)$, sodium borohydride $\left(\mathrm{NaBH}_{4}\right)$, absolute ethyl alcohol, sodium sulfate hydrate $\left(\mathrm{Na}_{2} \mathrm{SO}_{4} \cdot 10 \mathrm{H}_{2} \mathrm{O}\right)$ potassium dichromate $\left(\mathrm{K}_{2} \mathrm{Cr}_{2} \mathrm{O}_{7}\right)$, bisphenol A (BPA), hydrogen peroxide $\left(\mathrm{H}_{2} \mathrm{O}_{2}\right)$, and 1,10phenanthroline, were purchased from Sinopharm Chemical Reagent Co., Ltd. (Shanghai, China). Deionized water $\left(\geq 18.0 \mathrm{M} \Omega \mathrm{cm}^{-1}\right)$ was deoxygenated by high-purity nitrogen purging for $1 \mathrm{~h}$ before use.

\subsection{Preparation $n Z V I$ and $S-n Z V I$}

nZVI and S-nZVI nanoparticles were prepared according to our previous research [17]. Firstly, $50 \mathrm{~mL}$ of $\mathrm{NaBH}_{4}(0.036 \mathrm{~mol} / \mathrm{L})$ and $100 \mathrm{~mL}$ of $\mathrm{FeSO}_{4} \cdot 7 \mathrm{H}_{2} \mathrm{O}(0.018 \mathrm{~mol} / \mathrm{L})$ was added dropwise into a three-neck flask under $\mathrm{N}_{2}$ protection. Then, the resulting nZVI 
suspensions in the three-neck flask were magnetically separated and rinsed with anaerobic water and ethanol three times.

To obtain S-nZVI, prepared $\mathrm{FeSO}_{4} \cdot 7 \mathrm{H}_{2} \mathrm{O}$ solution was mixed with nZVI to obtain uniform dispersion, and then $\mathrm{Na}_{2} \mathrm{~S}$ solution was added dropwise into the flask and the mixture was stirred continuously for $20 \mathrm{~min}$. Finally, the zero-valent iron was magnetically separated and rinsed as described above, and vacuum-dried at $50{ }^{\circ} \mathrm{C}$ overnight. The whole preparation process was performed under a $\mathrm{N}_{2}$ atmosphere.

\subsection{Experimental Procedures}

The synchronous $\mathrm{Cr}(\mathrm{VI})$ sequestration and BPA degradation were conducted in a $250 \mathrm{~mL}$ beaker with $100 \mathrm{~mL}$ solution open to the atmosphere. The initial concentration of $\mathrm{Cr}(\mathrm{VI})$ and BPA was the same: $5 \mathrm{mg} / \mathrm{L}$. Unless otherwise specified, an aliquot of stock solution of $\mathrm{H}_{2} \mathrm{O}_{2}(0.2 \mathrm{mmol} / \mathrm{L})$ and S-nZVI $(50 \mathrm{mg} / \mathrm{L})$ was sequentially injected as a trigger for the reaction. At specific time intervals, $2 \mathrm{~mL}$ of samples were periodically collected and immediately mixed with $2 \mathrm{~mL}$ of ethanol to terminate the reaction, then filtered with $0.22 \mu \mathrm{m}$ PTFE membrane filters for further analysis. The effects of initial $\mathrm{pH}$, oxidant dosage, and catalyst dosage on synchronous removal of BPA and $\mathrm{Cr}(\mathrm{VI})$ by S-nZVI/ $\mathrm{H}_{2} \mathrm{O}_{2}$ system were investigated. Specifically, latent co-existing water anions $\left(\mathrm{HCO}_{3}{ }^{-}, \mathrm{H}_{2} \mathrm{PO}_{4}{ }^{-}\right.$, $\mathrm{NO}_{3}{ }^{-}$) and humic acid (HA) were also examined to obtain a better understanding of their adaptability in an aquatic environment. All experiments were conducted in duplicate.

To investigate the free radical species, ethanol $(2 \mathrm{mmol} / \mathrm{L})$ was added as a radical scavenger and 5,5-dimethyl-1-pyrroline-N-oxide (DMPO) was used as a spin trap agent for electron paramagnetic resonance (EPR) analysis (EMX-8/2.7C, Bruker, Germany) [18]. Synchronous removal of BPA and $\mathrm{Cr}(\mathrm{VI})$ with or without $o$-phenanthroline (o-phenanthroline: S-nZVI = 10:1) was performed to investigate the effect of Fe(II).

\subsection{Analysis}

The surface morphologies and element mappings of the S-nZVI were observed by scanning electron microscopy (SEM) (ZEISS Ultra 55., Germany) combined with energy dispersive X-ray spectroscopy (EDX). The mineralogical identity and structures were determined by a D/Max-IIIA Powder X-ray Diffractometer (XRD) (Rigaku Corp., Tokyo, Japan) equipped with $\mathrm{Cu}-\mathrm{K}_{\alpha}$ radiation. The surface compositions of the S-nZVI were determined by X-ray photoelectron spectroscopy (XPS) (Thermo-VG Scientific ESCALB250 with $\mathrm{Al}-\mathrm{K} \alpha$ radiation).

The concentration of BPA was measured by high-performance liquid chromatography (HPLC, LBP, 3000, RIGOL, Beijing, China). Cr(VI) was measured using a UV-vis spectrometer for the 1,5-diphenylcarbazide colorimetric method at a wavelength of $544 \mathrm{~nm}$, and the concentration of total chromium was determined by flame atomic adsorption spectrometry (Flame-AAS, 240, Agilent, Santa Clara, CA, USA). Cr(III) was identified by calculating the difference between the total chromium concentration and $\mathrm{Cr}(\mathrm{VI})$. Hydrogen peroxide was examined by a UV-vis spectrophotometer at $400 \mathrm{~nm}$ after coloration with $\mathrm{Ti}\left(\mathrm{SO}_{4}\right)_{2}$. The concentration of ferrous ions was measured by the $o$-phenanthroline method at wavelength of $510 \mathrm{~nm}$. The concentration of total iron ions was measured by adding hydroxylamine hydrochloride to reduce ferric ions into ferrous ions. Total organic carbon (TOC) was determined by TOC analyzer (Liqui TOC II).

\section{Results and Discussion}

\subsection{Characterization of $S-n Z V I$}

The surface morphology and element distribution of pristine S-nZVI was characterized by SEM-EDX as well as TEM. As shown in Figures S1 and S2, the spherical particles of Fe are covered with a thin layer of micrometer-sized material, which can be attributed to FeS. In addition, peaks of Fe and S elements were observed in the EDS mapping (Figure S1c). As shown in Figure S3, both S-nZVI and nZVI shows shrill $2 \theta$ peaks at $44.79^{\circ}$, which correspond to the [110] directions of $\alpha$-Fe, indicating the high purity and crystallinity of 
$\mathrm{Fe}^{0}$. Moreover, the diffraction peak of S-nZVI was much lower than that of nZVI, because the $\mathrm{Fe}^{0}$ core was encapsulated by a coverage of amorphous FeS. The above characterization indicates that S-nZVI is a core-shell structure with a coverage of FeS.

\section{2. $\mathrm{Cr}(\mathrm{VI})$ and BPA Removal in Different Systems}

The different systems on synchronous removal of BPA and $\mathrm{Cr}(\mathrm{VI})$ were investigated. As shown in Figure 1a, only 8.6-11.3\% of BPA was removed when $\mathrm{H}_{2} \mathrm{O}_{2}$ or nZVI or SnZVI were used individually during the reaction. However, the removal rates of BPA by $\mathrm{nZVI} / \mathrm{H}_{2} \mathrm{O}_{2}$ and S-nZVI/ $\mathrm{H}_{2} \mathrm{O}_{2}$ systems were $97.7 \%$ and $98.5 \%$ after $20 \mathrm{~min}$, respectively, indicating that the oxidative role of $\mathrm{H}_{2} \mathrm{O}_{2}$ should be activated to produce reactive species responsible for the degradation of BPA (Equations (3) and (4)) [19]. Noteworthily, the coupling of S-nZVI with $\mathrm{H}_{2} \mathrm{O}_{2}$ presented the highest efficiency for the degradation of BPA, and sulfur promotes the nZVI corrosion with generation of more hydroxyl radicals for BPA degradation [20]. Upon the detection of TOC variation (Figure S4), it was found that rapid TOC removal was achieved during the initial stage of the reaction. Then, after $10 \mathrm{~min}$ reaction, more TOC was gradually removed, and finally, $67.7 \%$ of TOC was eliminated in the S-nZVI/ $\mathrm{H}_{2} \mathrm{O}_{2} / \mathrm{Cr} / \mathrm{BPA}$ system. This result suggests that a considerable amount of BPA can be mineralized to carbon dioxide and water in the reaction. Interestingly, it was observed that $34.9 \%$ of $\mathrm{Cr}(\mathrm{VI})$ was removed by $\mathrm{H}_{2} \mathrm{O}_{2}$ alone within 60 min (Figure $1 \mathrm{~b}$ ). As a strong oxidant, $\mathrm{K}_{2} \mathrm{Cr}_{2} \mathrm{O}_{7}\left(\mathrm{E}^{0}=1.33 \mathrm{~V}\right)$ can be reduced by $\mathrm{H}_{2} \mathrm{O}_{2}\left(\mathrm{E}^{0}=0.678 \mathrm{~V}\right)$ according to Equation (5) [21]. Furthermore, $22.8 \%$ and $28.8 \%$ of $\mathrm{Cr}(\mathrm{VI})$ were removed by $\mathrm{nZVI} / \mathrm{H}_{2} \mathrm{O}_{2}$ and S-nZVI/ $\mathrm{H}_{2} \mathrm{O}_{2}$ systems after $5 \mathrm{~min}$, respectively, values which were lower than those obtained for nZVI (70.9\%) and S-nZVI (76.3\%) systems. The reaction rate of $\mathrm{Fe}^{2+} / \mathrm{H}_{2} \mathrm{O}_{2}$ $\left(2.58 \sim 3.14 \mathrm{~min}^{-1}\right)$ is much higher than that of $\mathrm{Cr}(\mathrm{VI})$ with $\mathrm{Fe}^{2+}\left(0.0763 \sim 0.1078 \mathrm{~min}^{-1}\right)$, and the produced $\cdot \mathrm{OH}$ could oxidize $\mathrm{Cr}$ (III) back to $\mathrm{Cr}(\mathrm{VI})$ [22]. Noteworthily, the removal efficiency of $\mathrm{Cr}(\mathrm{VI})$ in $\mathrm{H}_{2} \mathrm{O}_{2} / \mathrm{S}-\mathrm{nZVI}$ system (79.4\%) was much higher than that of the $\mathrm{H}_{2} \mathrm{O}_{2} / \mathrm{nZVI}$ system (37.5\%) after $10 \mathrm{~min}$, indicating the better performance of S-nZVI compared to nZVI (Equations (6)-(8)). After 20-30 min, both $\mathrm{H}_{2} \mathrm{O}_{2} / \mathrm{nZVI}$ and $\mathrm{H}_{2} \mathrm{O}_{2} / \mathrm{S}$ nZVI systems achieved over $95 \%$ of $\mathrm{Cr}(\mathrm{VI})$ removal, close to that obtained by nZVI $(97.8 \%)$ and S-nZVI (98.2\%). The above results clearly suggest that the synchronous removal of BPA and $\mathrm{Cr}(\mathrm{VI})$ can be successfully achieved in nZVI-based Fenton-like systems, and S-nZVI performed better than bare nZVI.

$$
\begin{gathered}
\mathrm{Fe}^{2+}+\mathrm{H}_{2} \mathrm{O}_{2} \rightarrow \mathrm{Fe}^{3+}+\cdot \mathrm{OH}+\mathrm{OH}^{-} \\
\mathrm{Cr}(\mathrm{n})+\mathrm{H}_{2} \mathrm{O}_{2} \rightarrow \mathrm{Cr}(\mathrm{n}+1)+\cdot \mathrm{OH}+\mathrm{OH}^{-}(\mathrm{n}=\mathrm{IV} \text { or } \mathrm{V}) \\
2 \mathrm{HCrO}_{4}{ }^{-}+8 \mathrm{H}^{+}+3 \mathrm{H}_{2} \mathrm{O}_{2} \rightleftharpoons 2 \mathrm{Cr}_{3}{ }^{+}+3 \mathrm{O}_{2}+8 \mathrm{H}_{2} \mathrm{O} \\
\mathrm{S}^{2-}+\mathrm{Cr}_{2} \mathrm{O}_{7}{ }^{2-}+2 \mathrm{H}^{+} \rightarrow \mathrm{SO}_{3}{ }^{2-}+\mathrm{Cr}(\mathrm{OH})_{3} \downarrow+\mathrm{H}_{2} \mathrm{O} \\
\mathrm{Cr}_{2} \mathrm{O}_{7}{ }^{2-}+6 \mathrm{Fe}^{2+}+14 \mathrm{H}^{+} \rightarrow 6 \mathrm{Fe}^{3+}+2 \mathrm{Cr}^{3+}+7 \mathrm{H}_{2} \mathrm{O} \\
\mathrm{Cr}_{2} \mathrm{O}_{7}{ }^{2-}+3 \mathrm{Fe}^{0}+14 \mathrm{H}^{+} \rightarrow 3 \mathrm{Fe}^{3+}+2 \mathrm{Cr}^{3+}+7 \mathrm{H}_{2} \mathrm{O}
\end{gathered}
$$

To further detect the interaction of BPA and $\mathrm{Cr}(\mathrm{VI})$ in a S-nZVI/ $\mathrm{H}_{2} \mathrm{O}_{2}$ system, the effect of one contaminant on the other contaminant was investigated via batch experiments. For example, the effects of BPA on $\mathrm{Cr}(\mathrm{VI})$ removal were studied with different initial concentrations. Figure 1c shows that the degradation efficiency of BPA decreased when $\mathrm{Cr}(\mathrm{VI})$ was added into the S-nZVI/ $\mathrm{H}_{2} \mathrm{O}_{2}$ system, because $\mathrm{Cr}(\mathrm{VI})$ consumed the reductive Fe species and also reacted with $\mathrm{H}_{2} \mathrm{O}_{2}$. Therefore, the degradation of BPA was eventually inhibited with increasing dosage of $\mathrm{Cr}(\mathrm{VI})$, inactivating more $\mathrm{H}_{2} \mathrm{O}_{2}$ and decreasing the yield of hydroxyl radicals (Figure 1e). Conversely, the presence of BPA showed no significant inhibitory effect, but rather a positive promotion of $\mathrm{Cr}(\mathrm{VI})$ removal (Figure 1d). However, it was noticed that this promotion was not further enhanced with increasing BPA concentration (Figure 1f). The competitive reaction between BPA and $\mathrm{H}_{2} \mathrm{O}_{2}$ seemed to protect $\mathrm{Cr}(\mathrm{VI})$ from oxidation and facilitate its reduction on the S-nZVI surface. 
(a)

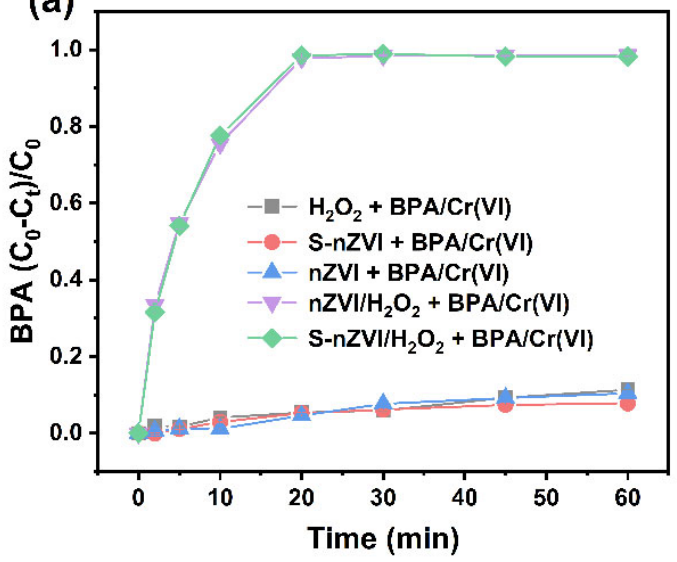

(c)
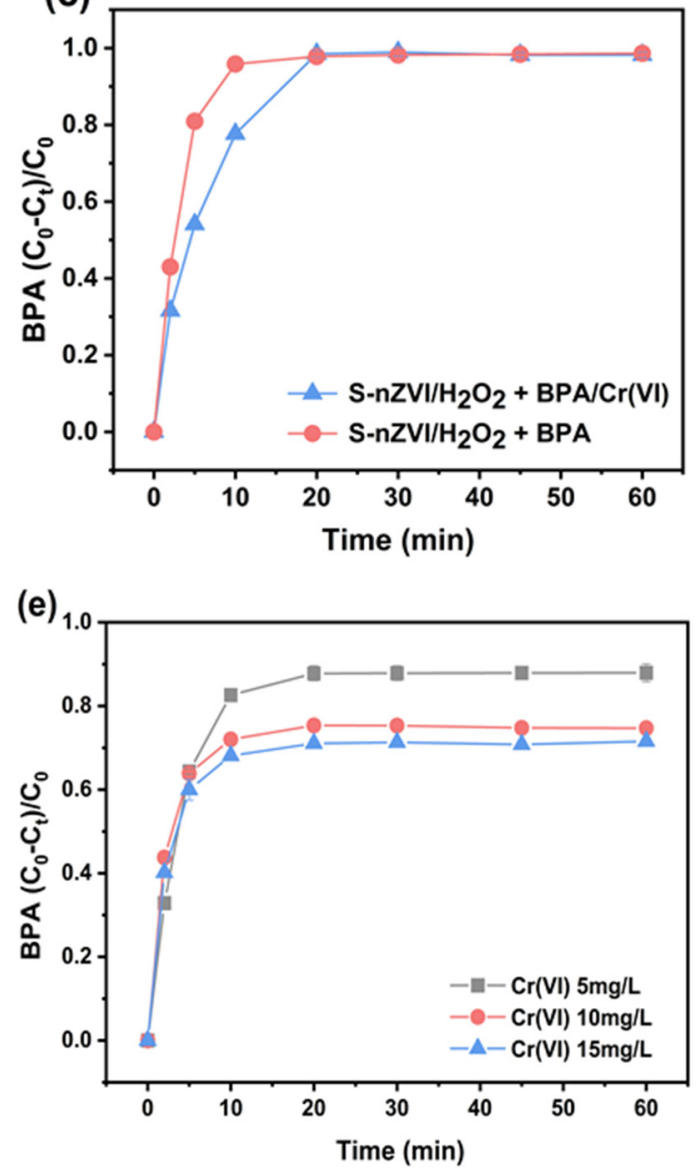
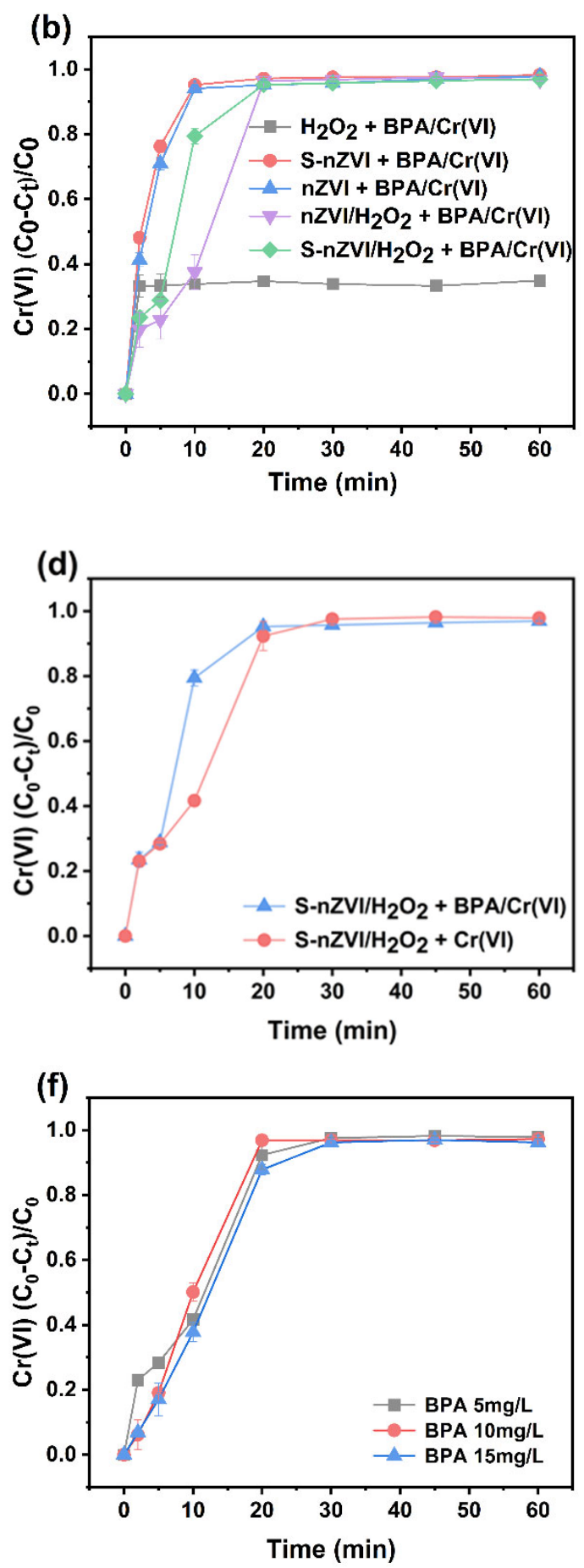

Figure 1. Synchronous removal of (a) BPA and (b) $\mathrm{Cr}(\mathrm{VI})$ in different reaction systems; removal of BPA (c) or $\mathrm{Cr}(\mathrm{VI})$ (d) alone by S-nZVI/ $\mathrm{H}_{2} \mathrm{O}_{2}$; the degradation of BPA under different $\mathrm{Cr}(\mathrm{VI})$ concentrations (e) and the reduction of $\mathrm{Cr}(\mathrm{VI})$ at different BPA concentrations (f).

In the past decade, $\mathrm{SO}_{4} \cdot{ }^{-}$-based advanced oxidation processes using PS as the oxidant have been studied intensively for wastewater treatment. In comparison with the S-nZVI/PS Fenton-like system, as shown in Figure S5, S-nZVI/ $\mathrm{H}_{2} \mathrm{O}_{2}$ exhibited a significantly higher efficiency in BPA oxidation, indicating a higher oxidation capacity of S-nZVI $/ \mathrm{H}_{2} \mathrm{O}_{2}$ than S-nZVI/PS. Conversely, $\mathrm{Cr}(\mathrm{VI})$ seemed to be removed more quickly in the S-nZVI/PS system than in the S-nZVI/ $\mathrm{H}_{2} \mathrm{O}_{2}$ system, implying a lower interference of PS activation on $\mathrm{Cr}(\mathrm{VI})$. This result is consistent with that reported by Diao et al., where $\mathrm{Cr}(\mathrm{VI})$ removal was negligibly influenced by PS in the nZVI/PS system. However, after 20 min reaction, 
the difference between the two reaction schemes was really minor, and was surprisingly uniform after $30 \mathrm{~min}$. The reduction of $\mathrm{Cr}(\mathrm{VI})$ after $30 \mathrm{~min}$ was over $95 \%$, and achieved equilibrium in the remaining reaction time. Considering the joint removal performance of BPA and $\mathrm{Cr}(\mathrm{VI})$, the $\mathrm{S}-\mathrm{nZVI} / \mathrm{H}_{2} \mathrm{O}_{2}$ system seemingly showed a more comprehensive potential than S-nZVI/PDS with respect to the treatment of co-contamination of BPA and $\mathrm{Cr}(\mathrm{VI})$.

\subsection{Effect of $p H$, Oxidant Dosage, Catalyst Dosage}

It was observed that $\mathrm{Cr}(\mathrm{VI})$ reduction and BPA oxidation were dependent on varying pH conditions (Figure S6a). Approximately $90 \%$ of BPA was removed after $20 \mathrm{~min}$ at $\mathrm{pH}=3$, whereas there was almost no obvious BPA degradation at pH 7.0 and 9.0, indicating that BPA removal increased with decreasing initial $\mathrm{pH}$ value, which might be attributed to the generation of more hydroxyl radicals by $\mathrm{S}-\mathrm{nZVI} / \mathrm{H}_{2} \mathrm{O}_{2}$ in acidic conditions [23]. It was observed that $97.8 \%, 54.6 \%, 57.6 \%, 53.1 \%$ and $45.5 \%$ of $\mathrm{Cr}(\mathrm{VI})$ removal were obtained at $\mathrm{pH}$ values of 3, 4, 5, 7 and 9, respectively (Figure S6b). This suggests that acidic conditions favor $\mathrm{Cr}$ (VI) removal. More indissoluble $\mathrm{Fe}^{3+}$ hydroxide was precipitated with $\mathrm{Cr}$ (III) to form a Fe-Cr hydroxide layer under neutral or alkaline conditions [17]. These precipitates on nZVI surface occupy active sites, limiting $\mathrm{Fe}^{2+}$ release, and retarding electron transfer from S-nZVI to $\mathrm{Cr}(\mathrm{VI})$ [24]. In addition, the oxidation potential of $\cdot \mathrm{OH}$ decreased along with the increase in solution $\mathrm{pH}$, from $2.65-2.80 \mathrm{~V}$ at $\mathrm{pH} 3.0$ to $1.90 \mathrm{~V}$ at $\mathrm{pH} 7.0$, as previously reported [19]. Nevertheless, some researchers have reported that $\mathrm{Cr}(\mathrm{VI})$ sequestration by nano- $\mathrm{FeS}_{2}$ increases notably with an increase in suspension $\mathrm{pH}$ from 5.0 to 9.0 [25]. This is because $S^{2-}$ plays a primary role in the reactive surface of nano-FeS $S_{2}$, having higher nucleophilicity in an alkaline solution, and may enhance the reduction of $\mathrm{Cr}(\mathrm{VI})$. In this work, $\mathrm{Cr}(\mathrm{VI})$ was completely removed at $\mathrm{pH} 3$, while approximately $50 \% \mathrm{Cr}$ (VI) removal was obtained under other $\mathrm{pH}$ conditions, indicating that acidic conditions $(\mathrm{pH}=3)$ were conducive to $\mathrm{Cr}(\mathrm{VI})$ removal.

The influence of oxidant dosage on the synchronous removal of $\mathrm{Cr}(\mathrm{VI})$ and BPA in the S-nZVI/ $\mathrm{H}_{2} \mathrm{O}_{2}$ system is depicted in Figure S6c,d. The BPA removal rate increased from $88.5 \%$ to $98.0 \%$ after 20 min when the amount of oxidant added to the system was increased from $0.2 \mathrm{mmol} / \mathrm{L}$ to $0.4 \mathrm{mmol} / \mathrm{L}$ (Figure S6c). These results conclusively demonstrate the key role played by $\mathrm{H}_{2} \mathrm{O}_{2}$ in the generation of $\cdot \mathrm{OH}$ for BPA degradation in this system. Interestingly, despite there being no obvious difference observed in BPA removal when the $\mathrm{H}_{2} \mathrm{O}_{2}$ dosages were in the range of 0.4 to $0.8 \mathrm{mmol} / \mathrm{L}$, the reaction constant decreased from $0.298 \mathrm{~min}^{-1}$ to $0.209 \mathrm{~min}^{-1}$. In fact, excessive $\mathrm{H}_{2} \mathrm{O}_{2}$ could cause the release of a mass of $\cdot \mathrm{OH}$, resulting in the self-quenching of hydroxyl radicals, as shown in Equations (9) and (10) [25].

$$
\begin{gathered}
\mathrm{H}_{2} \mathrm{O}_{2}+\mathrm{OH} \cdot \rightarrow \mathrm{H}_{2} \mathrm{O}+\cdot \mathrm{O}_{2} \mathrm{H} \\
\cdot \mathrm{O}_{2} \mathrm{H}+\mathrm{OH} \cdot \rightarrow \mathrm{H}_{2} \mathrm{O}+\mathrm{O}_{2}
\end{gathered}
$$

As shown in Figure S6d, when the $\mathrm{H}_{2} \mathrm{O}_{2}$ dosages exceeded $0.4 \mathrm{mmol} / \mathrm{L}, \mathrm{Cr}(\mathrm{VI})$ removal rapidly increased during the first $2 \mathrm{~min}$, then the amount of $\mathrm{Cr}(\mathrm{VI})$ gradually decreased, but an increase in $\mathrm{Cr}(\mathrm{VI})$ removal was observed after $30 \mathrm{~min}$, meaning that $\mathrm{Cr}(\mathrm{VI})$ removal decreased with increasing $\mathrm{H}_{2} \mathrm{O}_{2}$ dosage. This may be due to the generation of hydroxyl radicals with increasing $\mathrm{H}_{2} \mathrm{O}_{2}$ dosage, causing $\mathrm{Cr}$ (III) to be reconverted into $\mathrm{Cr}(\mathrm{VI})$ and the competition between excess $\mathrm{H}_{2} \mathrm{O}_{2}$ and $\mathrm{Fe}^{2+}$, which could quickly remove $\mathrm{Cr}(\mathrm{VI})$. Therefore, the larger the oxidant dosage, the slower the removal rate of $\mathrm{Cr}(\mathrm{VI})$ at $\mathrm{H}_{2} \mathrm{O}_{2}$ concentrations higher than $0.4 \mathrm{mmol} / \mathrm{L}$. In addition, the dosage of S-nZVI is also a vital control variable for BPA and $\mathrm{Cr}(\mathrm{VI})$ removal. As shown in Figure S6e,f, the increment of S-nZVI significantly accelerated the synchronous removal of BPA and Cr(VI) when increasing the S-nZVI dosage from 0.02 to $0.15 \mathrm{~g} / \mathrm{L}$. Specifically, the reaction kinetics constant of BPA degradation increased from $0.088 \mathrm{~min}^{-1}$ to $0.276 \mathrm{~min}^{-1}$. Increasing the dosage of S-nZVI provided more active sites for not only Fenton-like catalysis, but also Cr(VI) sequestration. In addition, the ultimate removal rates of BPA and $\mathrm{Cr}(\mathrm{VI})$ were similar when 
the S-nZVI dosage was increased from 0.05 to $0.15 \mathrm{~g} / \mathrm{L}$. Hence, considering the cost and practical application of S-nZVI, $0.05 \mathrm{~g} / \mathrm{L}$ of it was chosen for the subsequent experiments.

\subsection{Effect of Water Matrices}

Humic acid (HA) and coexisting water anions (including $\mathrm{HCO}_{3}{ }^{-}, \mathrm{NO}_{3}{ }^{-}, \mathrm{H}_{2} \mathrm{PO}_{4}{ }^{-}$) are widely present in the environment and interfere with the process of environmental restoration. As shown in Figure 2a, the removal of BPA decreased from 97.7\% to 63.7\% when HA concentration was increased from 0 to $50 \mathrm{mg} / \mathrm{L}$. Since humic acid is a kind of organic substance, it competes with BPA to quench $\cdot \mathrm{OH}$, resulting in a decrease in BPA degradation rate [26]. Additionally, humic acid might integrate with surface iron (such as $\mathrm{Fe}^{2+}, \mathrm{Fe}^{3+}$ and $\mathrm{Fe}(0)$ ) to form dissolved $\mathrm{Fe}-$ humate complexes, causing a loss of reducing substances as well as decreasing the removal efficiency of BPA [27]. However, when a small amount of HA ( $5 \mathrm{mg} / \mathrm{L})$ was spiked into the reaction solution, almost no influence on $\mathrm{Cr}(\mathrm{VI})$ removal was observed (Figure 2b). In particular, humic acid also acts as an additional adsorbent and electron transfer mediator at tiny concentrations due to its multiple functional groups [28], which ultimately offset the negative impact of highly concentrated $\mathrm{HA}$ for $\mathrm{Cr}(\mathrm{VI})$ removal.
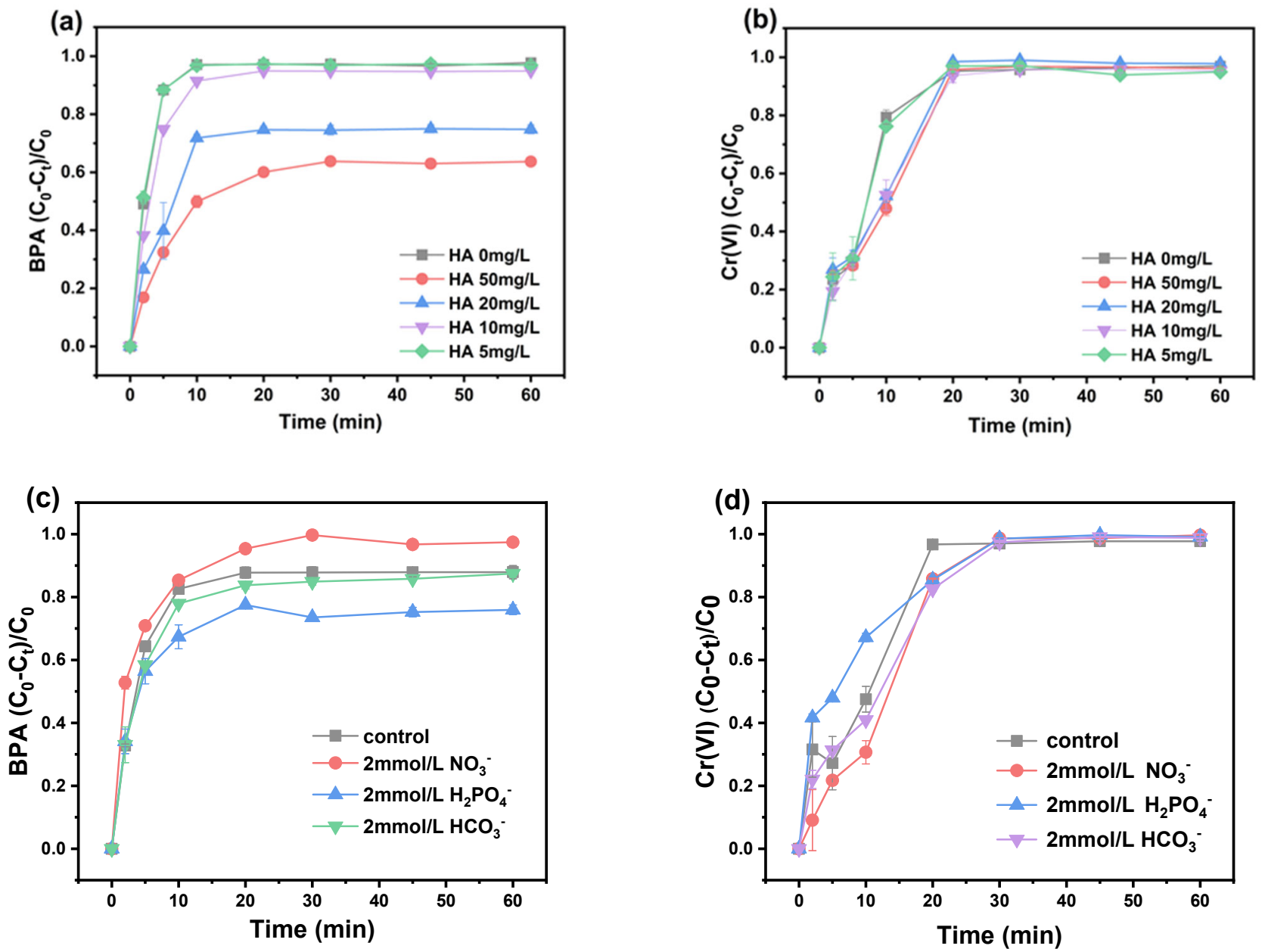

Figure 2. Effect of $(\mathbf{a}, \mathbf{b})$ humic acid and $(\mathbf{c}, \mathbf{d})$ inorganic anions on synchronous removal of BPA and Cr(VI) by S-nZVI.

As presented in Figure 2c, d, the removal rate of both BPA and $\mathrm{Cr}(\mathrm{VI})$ by S-nZVI $/ \mathrm{H}_{2} \mathrm{O}_{2}$ was significantly influenced in the presence of $\mathrm{NO}_{3}{ }^{-}$and $\mathrm{H}_{2} \mathrm{PO}_{4}{ }^{-}$, but slightly suppressed by $\mathrm{HCO}_{3}{ }^{-}$. The slight inhibition of $\mathrm{HCO}_{3}{ }^{-}$here could be because of its reaction with $\mathrm{Fe}^{2+}$ to form $\mathrm{FeCO}_{3}$ or hydroxyl carbonate, which attached to the surface of S-nZVI, resulting 
in a decrease in iron ions and reactive sites [28]. However, in the presences $^{-\mathrm{NO}_{3}}{ }^{-}$, the removal efficiency of BPA increased from $98.9 \%$ to $99.7 \%$, while the initial removal efficiency of $\mathrm{Cr}(\mathrm{VI})$ increased from $95.7 \%$ to $98.7 \%$ in $30 \mathrm{~min}$. This is probably because $\mathrm{NO}_{3}{ }^{-}$competes with $\mathrm{Cr}(\mathrm{VI})$ for reactive sites in S-nZVI and produces more $\mathrm{Fe}(\mathrm{II})$ at the solid-liquid interface (as per Equations (11) and (12)) [20]. Moreover, $\mathrm{H}_{2} \mathrm{PO}_{4}{ }^{-}$showed a different effect, wherein the rate of BPA removal decreased from $98.2 \%$ to $75.9 \%$ while the $\mathrm{Cr}(\mathrm{VI})$ removal increased from $96.9 \%$ to $99.1 \%$. Firstly, this could be because $\mathrm{H}_{2} \mathrm{PO}_{4}{ }^{-}$can complex with $\mathrm{Cr}(\mathrm{VI})$ to form a water-soluble complex [29], preventing the formation of a zero-valent iron surface passivation layer and improving the removal of $\mathrm{Cr}(\mathrm{VI})$. Secondly, $\mathrm{H}_{2} \mathrm{PO}_{4}{ }^{-}$is a typical radical scavenger, thus inhibiting the degradation of BPA [30].

$$
\begin{gathered}
\mathrm{Fe}^{0}+\mathrm{NO}_{3}{ }^{-}+2 \mathrm{H}^{+} \rightarrow \mathrm{Fe}^{2+}+\mathrm{H}_{2} \mathrm{O}+\mathrm{NO}_{2}{ }^{-} \\
4 \mathrm{Fe}^{0}+\mathrm{NO}_{3}{ }^{-}+10 \mathrm{H}^{+} \rightarrow 4 \mathrm{Fe}^{2+}+3 \mathrm{H}_{2} \mathrm{O}+\mathrm{NH}_{4}{ }^{+}
\end{gathered}
$$

\subsection{Proposed Reaction Mechanism}

Accordingly, it can be deduced that BPA was degraded by activating $\mathrm{H}_{2} \mathrm{O}_{2}$ with SnZVI, but the removal of $\mathrm{Cr}(\mathrm{VI})$ was achieved by ferrous on S-nZVI surface. To clarify the role of $\mathrm{Fe}(\mathrm{II})$ on BPA and $\mathrm{Cr}(\mathrm{VI})$ elimination, o-phenanthroline was added into the reaction system as a $\mathrm{Fe}(\mathrm{II})$ shielding agent. As shown in Figure 3a,b, the removal of $\mathrm{Cr}(\mathrm{VI})$ and BPA was significantly inhibited after adding $o$-phenanthroline. The BPA removal rate decreased from $97.7 \%$ to $29.1 \%$, and the $\mathrm{Cr}(\mathrm{VI})$ removal rate decreased from $97.8 \%$ to $17.6 \%$, implying that $\mathrm{Fe}(\mathrm{II})$ not only participated in the Fenton reaction as an activator of $\mathrm{H}_{2} \mathrm{O}_{2}$, but also reduced $\mathrm{Cr}(\mathrm{VI})$ into $\mathrm{Cr}(\mathrm{III})$ as an electron donor [31]. In addition, the $\mathrm{H}_{2} \mathrm{O}_{2}$ use rates were determined for different systems as shown in Figure 3c. It can be observed that $\mathrm{H}_{2} \mathrm{O}_{2}$ was completely used in $60 \mathrm{~min}$ for the $\mathrm{H}_{2} \mathrm{O}_{2} / \mathrm{S}-\mathrm{nZVI} / \mathrm{BPA} / \mathrm{Cr}$ system, while $82.4 \%$ and $68.8 \%$ were achieved for the $\mathrm{H}_{2} \mathrm{O}_{2} / \mathrm{S}$-nZVI/BPA and $\mathrm{H}_{2} \mathrm{O}_{2} / \mathrm{S}-\mathrm{nZVI} / \mathrm{Cr}(\mathrm{VI})$ systems, respectively. Moreover, the use of $\mathrm{H}_{2} \mathrm{O}_{2}$ also reached $64.7 \%$ when S-nZVI was not added, due to the catalysis of chromium, which is consistent with the results in Figure 1, suggesting that $\mathrm{H}_{2} \mathrm{O}_{2}$ could be decomposed in presence of $\mathrm{Cr}(\mathrm{VI})$ via a redox process (Equations (14) and (15)). Both $\mathrm{Fe}$ and $\mathrm{Cr}$ species are able to react with $\mathrm{H}_{2} \mathrm{O}_{2}$, thus consuming more $\mathrm{H}_{2} \mathrm{O}_{2}$ than systems with a single contaminant [32].

$$
\begin{gathered}
\mathrm{HCrO}_{4}^{-}+2 \mathrm{H}_{2} \mathrm{O}_{2}+\mathrm{H}^{+} \rightleftharpoons \mathrm{CrO}\left(\mathrm{O}_{2}\right)_{2}+3 \mathrm{H}_{2} \mathrm{O} \\
2 \mathrm{CrO}\left(\mathrm{O}_{2}\right)_{2}+6 \mathrm{H}^{+} \rightleftharpoons 2 \mathrm{Cr}^{3+}+3 \mathrm{O}_{2}+\mathrm{H}_{2} \mathrm{O}_{2}+2 \mathrm{H}_{2} \mathrm{O}
\end{gathered}
$$

The catalytic activation of $\mathrm{H}_{2} \mathrm{O}_{2}$ is most likely to produce $\cdot \mathrm{OH}$ via a Haber-Weiss-type reaction [33]. As a typical $\cdot \mathrm{OH}$ quencher, ethanol was used to identify the presence of $\cdot \mathrm{OH}$ in the present reaction system, and the removal efficiencies of BPA with or without ethanol were evaluated. As observed in Figure 3d, 14.22\% of BPA was removed after 20 min in the presence of ethanol, whereas the removal rate of BPA was $89.92 \%$ without ethanol, suggesting an obvious inhibitory effect of ethanol on BPA degradation. In contrast, no significant difference was observed in $\mathrm{Cr}(\mathrm{VI})$ removal with scavenger (Figure 3e). The EPR technique with 5,5-dimethyl-1-pyrrolidine- $\mathrm{N}$-oxide (DMPO) as a spin-trapping agent was used to further identify the production of $\cdot \mathrm{OH}$ in the S-nZVI/ $\mathrm{H}_{2} \mathrm{O}_{2}$ system. As shown in Figure S7, there exists a characteristic peak with a peak height ratio of 1:2:2:1, and the signal intensity of DMPO-OH increased in first $2 \mathrm{~min}$ but then gradually decreased due to the consumption of $\mathrm{H}_{2} \mathrm{O}_{2}$. These results suggest that $\cdot \mathrm{OH}$ was the principal species responsible for BPA degradation in the S-nZVI/ $\mathrm{H}_{2} \mathrm{O}_{2} / \mathrm{Cr}(\mathrm{VI}) / \mathrm{BPA}$ reaction system. 
(a)

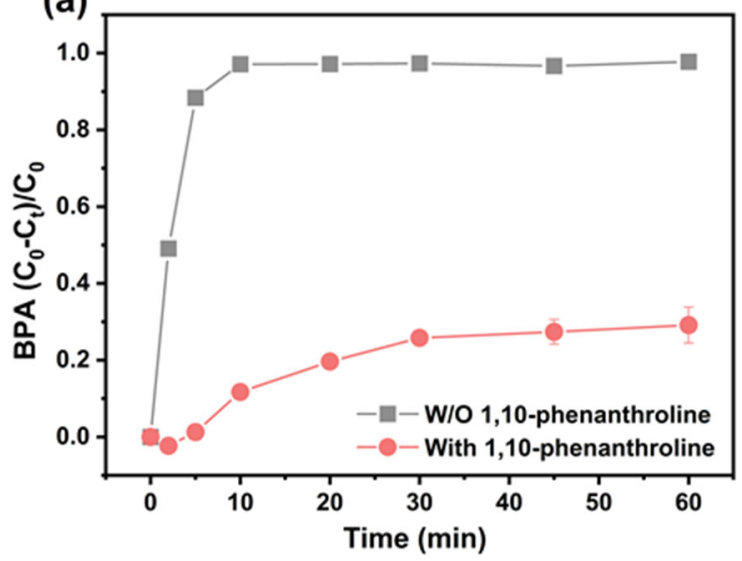

(c)

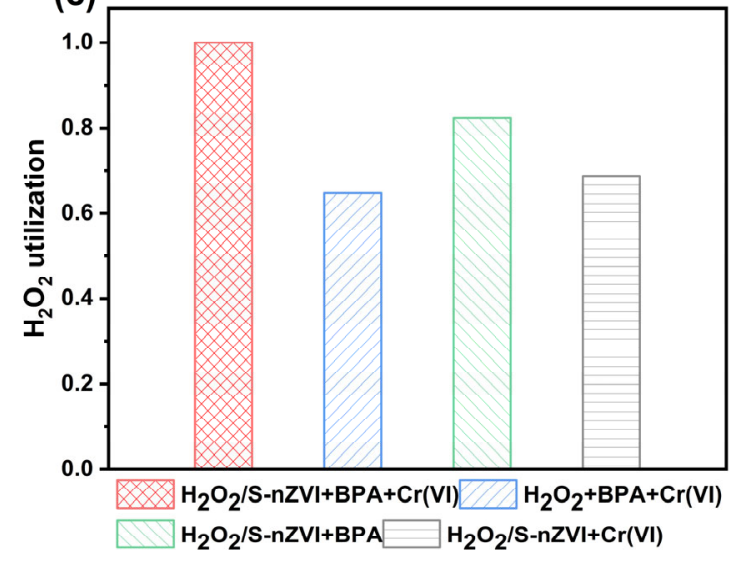

(e)

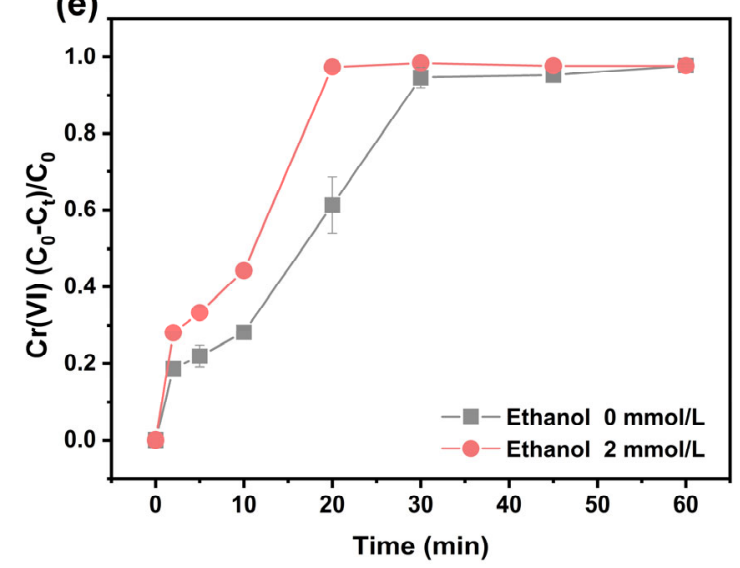

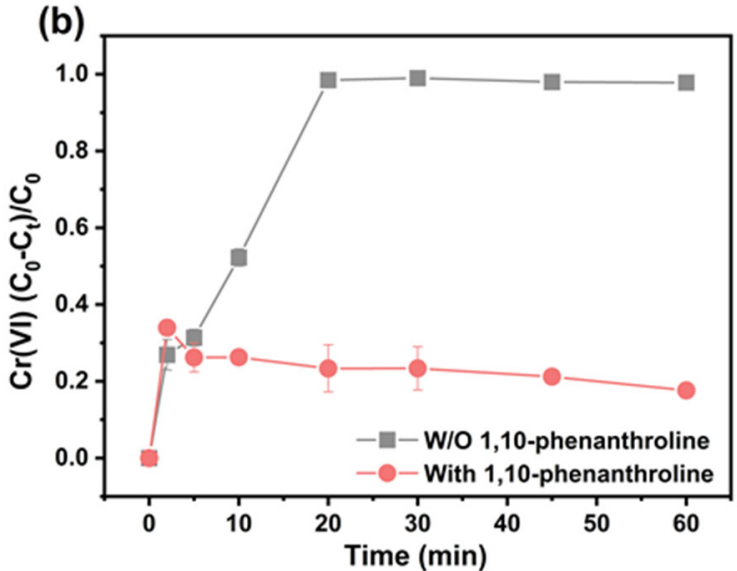

(d)
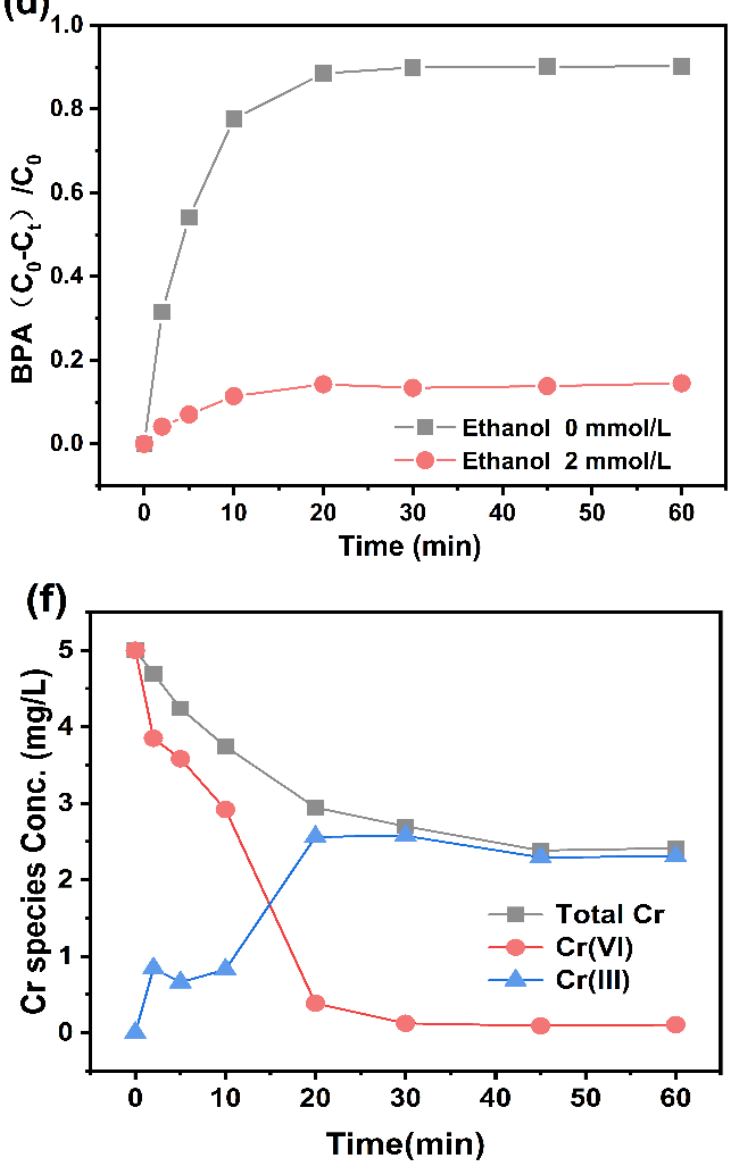

Figure 3. The synchronous removal of (a) BPA and (b) $\mathrm{Cr}(\mathrm{VI})$ by S-nZVI/ $/ \mathrm{H}_{2} \mathrm{O}_{2}$ with/without the presence of o-phenanthroline; (c) the use rate of hydrogen peroxide in different systems; the synchronous removal of (d) BPA, and (e) $\mathrm{Cr}(\mathrm{VI})$ by S-nZVI/ $\mathrm{H}_{2} \mathrm{O}_{2}$ with/without the presence of ethanol; (f) the concentration of $\mathrm{Cr}$ species in the solution.

The transformation of $\mathrm{Cr}(\mathrm{VI})$ is important for detoxification, and the species of aqueous $\mathrm{Cr}$ varies with S-nZVI reduction and - $\mathrm{OH}$ oxidation. As presented in Figure $3 \mathrm{f}$, the concentration of total $\mathrm{Cr}$ in solution decreased along with the elimination of $\mathrm{Cr}(\mathrm{VI})$. Aqueous chromium was continuously reduced and immobilized by S-nZVI, which is consistent with previous studies reporting that $\mathrm{Fe}^{0}$ corrodes and yields the iron (hydro)oxides to remove heavy metals throguh adsorption and co-precipitation [2]. However, it is worth noting that the concentration of total $\mathrm{Cr}$ at every time point is higher than that of $\mathrm{Cr}(\mathrm{VI})$. This result is different from that reported in our previous study, which indicated that the total 
$\mathrm{Cr}$ and $\mathrm{Cr}(\mathrm{VI})$ displayed almost same removal tendency [17]. This is because a significant portion of $\mathrm{Cr}(\mathrm{VI})$ was transformed to $\mathrm{Cr}(\mathrm{III})$ through the reaction with $\mathrm{H}_{2} \mathrm{O}_{2}$, and therefore was not captured by S-nZVI [34]. This phenomenon is evidenced by the variation of $\mathrm{Cr}$ species. For example, the concentration of $\mathrm{Cr}(\mathrm{III})$ decreased from $0.84 \mathrm{mg} / \mathrm{L}$ to $0.66 \mathrm{mg} / \mathrm{L}$ in $5 \mathrm{~min}$, which could be due to the reversible conversion of $\mathrm{Cr}$ species by $\cdot \mathrm{OH}$. In addition, $\mathrm{Cr}(\mathrm{VI})$ can be reduced by surface $\mathrm{Fe}^{2+}$ and $\mathrm{S}^{2-}$ from the corrosion of S-nZVI during the reaction process [4]. The newly formed $\mathrm{Cr}(\mathrm{III})$ and $\mathrm{Fe}(\mathrm{III})$ co-precipitate simultaneously on the S-nZVI to form Cr/Fe (oxy)-hydroxide, as per Equations (15) and (16) [35]. The reusability of S-nZVI was further investigated by separating S-nZVI with a magnet after the reaction, followed by washing in deionized water and subsequent reuse for synchronous removal of $\mathrm{Cr}(\mathrm{VI})$ and BPA. As presented in Figure S8, BPA can be fully degraded even when S-nZVI was reused three times, but the removal efficiency of $\mathrm{Cr}(\mathrm{VI})$ decreased along the number of times that S-nZVI was reused. In the third run, $69.2 \%$ of $\mathrm{Cr}(\mathrm{VI})$ was removed in the S-nZVI/ $\mathrm{H}_{2} \mathrm{O}_{2} / \mathrm{Cr} / \mathrm{BPA}$ reaction system. The deposition of Fe-Cr oxides impeded the smooth generation of ferrous species from S-nZVI corrosion, leading to a decline in performance for $\mathrm{Cr}(\mathrm{VI})$ sequestration.

$$
\begin{gathered}
x \mathrm{Cr}^{3+}+(1-\mathrm{x}) \mathrm{Fe}^{3+}+2 \mathrm{H}_{2} \mathrm{O} \rightarrow \mathrm{Cr}_{\mathrm{x}} \mathrm{Fe}_{1-\mathrm{x}} \mathrm{OOH} \downarrow+3 \mathrm{H}^{+} \\
x \mathrm{Cr}^{3+}+(1-\mathrm{x}) \mathrm{Fe}^{3+}+3 \mathrm{H}_{2} \mathrm{O} \rightarrow\left(\mathrm{Cr}_{\mathrm{x}} \mathrm{Fe}_{1-\mathrm{x}}\right)(\mathrm{OH})_{3} \downarrow+3 \mathrm{H}^{+}
\end{gathered}
$$

After the reaction, a thick iron oxide was formed on the S-nZVI surface, as indicated by the XRD spectrum (Figure S9). Compared to fresh S-nZVI, a new peak appeared at a $2 \theta$ angle of $35.6^{\circ}$, which attributed to the facet of hematite (110), implying the formation of iron oxides during the reaction. To better understand the mechanism of BPA elimination and $\mathrm{Cr}(\mathrm{VI})$ sequestration, the XPS spectra of S-nZVI were detected before and after the reaction. As shown in Figure $4 a$, the XPS spectra of Fe 2p on the surface of the pristine S-nZVI at $706.96 \mathrm{eV}$ corresponded to $\mathrm{Fe} 2 \mathrm{p}_{3 / 2}$ of $\mathrm{Fe}^{0}$ with low content of $2.55 \%$ [36]. The binding energies at $712.05 \mathrm{eV}$ and $726.11 \mathrm{eV}$, coupled with a satellite peak obtained at $719.07 \mathrm{eV}$ and $732.35 \mathrm{eV}$, respectively, were assigned to Fe $2 \mathrm{p}_{3 / 2}$ and Fe $2 \mathrm{p}_{1 / 2}$ of Fe (III) in terms of iron (oxy) hydroxide [37]. In addition, the peaks at $710.40 \mathrm{eV}$ and $724.01 \mathrm{eV}$ were attributed to Fe $2 \mathrm{p}_{3 / 2}$ and $\mathrm{Fe} 2 \mathrm{p}_{1 / 2}$ of Fe(II), respectively. These results demonstrate that the surface of S-nZVI was slightly oxidized and wrapped by a mixture of $\mathrm{Fe}(\mathrm{II})$ and $\mathrm{Fe}(\mathrm{III})$, which is consistent with the results of EDX analysis. After the reaction, it can be observed that the peak of $\mathrm{Fe}^{0}$ disappeared, and the molar ratio of $\mathrm{Fe}(\mathrm{II})$ remained nearly unchanged, while the $\mathrm{Fe}$ (III) fraction increased from $23.74 \%$ to $27.32 \%$, as depicted in Figure $4 \mathrm{a}$ and Table $\mathrm{S} 1$. Thus, it can be deduced that $\mathrm{Fe}^{0}$ was sacrificed as the electron donor and converted to $\mathrm{Fe}(\mathrm{II})$, which then reacted with $\mathrm{Cr}(\mathrm{VI})$ and $\mathrm{H}_{2} \mathrm{O}_{2}$, resulting in a redox transformation from Fe(II) to Fe(III) [35]. Moreover, four distinguishing peaks can be found in the S2p spectrum (Figure $4 \mathrm{~b}$ ). The binding energies at $161.37 \mathrm{eV}$ and $163.07 \mathrm{eV}$ were attributed to iron monosulfide $(\mathrm{FeS})$ and iron disulfide $\left(\mathrm{FeS}_{2}\right)$ [38], and the peaks with binding energy of $166.49 \mathrm{eV}$ and $168.42 \mathrm{eV}$ were attributed to $\mathrm{SO}_{3}{ }^{2-}$ and $\mathrm{SO}_{4}{ }^{2-}$, respectively [39]. After the reaction, the peak intensity of $\mathrm{S}^{2-}$ decreased from $56.45 \%$ to $14.65 \%$ (Table S1), but the peak intensities for $\mathrm{SO}_{3}{ }^{2-}$ and $\mathrm{SO}_{4}{ }^{2-}$ increased remarkably to $6.38 \%$ and $78.97 \%$, respectively, demonstrating the involvement of $\mathrm{S}^{2-}$ during the reductive adsorption of $\mathrm{Cr}(\mathrm{VI})$ and the catalytic activation of $\mathrm{H}_{2} \mathrm{O}_{2}$ for BPA degradation (Figure $4 \mathrm{~b}$ ). It has been verified that iron sulfides are able to act as good semiconductors or metallic conductors for S-nZVI, thus facilitating the electron transfer from the iron core to the adsorbed contaminants and facilitating the cycle of Fe(II)/Fe(III) [40]. The XPS spectrum of Cr was further tested to confirm the conversion of $\mathrm{Cr}(\mathrm{VI})$ to low-toxic $\mathrm{Cr}(\mathrm{III})$. After the reaction, as shown in Figure $4 \mathrm{c}$, the deconvolution peaks of $\mathrm{Cr} 2 \mathrm{p}$ at $577.16 \mathrm{eV}$ and $586.76 \mathrm{eV}$ corresponded to $\mathrm{Cr}_{2} \mathrm{O}_{3}$ [25], and the peaks at $577.37 \mathrm{eV}$ and $587.46 \mathrm{eV}$ were assigned to $\mathrm{Cr}(\mathrm{OH})_{3}$ [41], indicating that $\mathrm{Cr}(\mathrm{VI})$ sequestration by S-nZVI was primarily a process of chemisorption, with reduction of $\mathrm{Cr}(\mathrm{VI})$ to $\mathrm{Cr}(\mathrm{III})$. Additionally, the oxygen peaks with binding energies of $529.72 \mathrm{eV}$ and $531.11 \mathrm{eV}$ were assigned to $\mathrm{O}^{2-}$ and $\mathrm{OH}^{-}$(Figure $4 \mathrm{~d}$ ), suggesting the 
presence of iron oxide and hydroxyl species of Fe before use, respectively. After the reaction, the content of $\mathrm{O}^{2-}$ decreased from $31.98 \%$ to $15.65 \%$ while the content of $\mathrm{OH}^{-}$increased from $68.02 \%$ to $84.35 \%$ (Table S1), indicating the formation of hydroxides on the surface of S-nZVI. These results imply that both $\mathrm{Cr}(\mathrm{OH})_{3}$ and $\mathrm{Cr}(\mathrm{III}) / \mathrm{Fe}(\mathrm{III})$ (oxy)hydroxide were on the surface of S-nZVI after Cr(VI) sequestration. In addition, the atomic fraction of C-C component at a binding energy of 284.8 increased remarkably from 41.83 to 68.19 after the reaction (Figure S10), which may indicate an adventitious organic carbon contamination on S-nZVI surface.
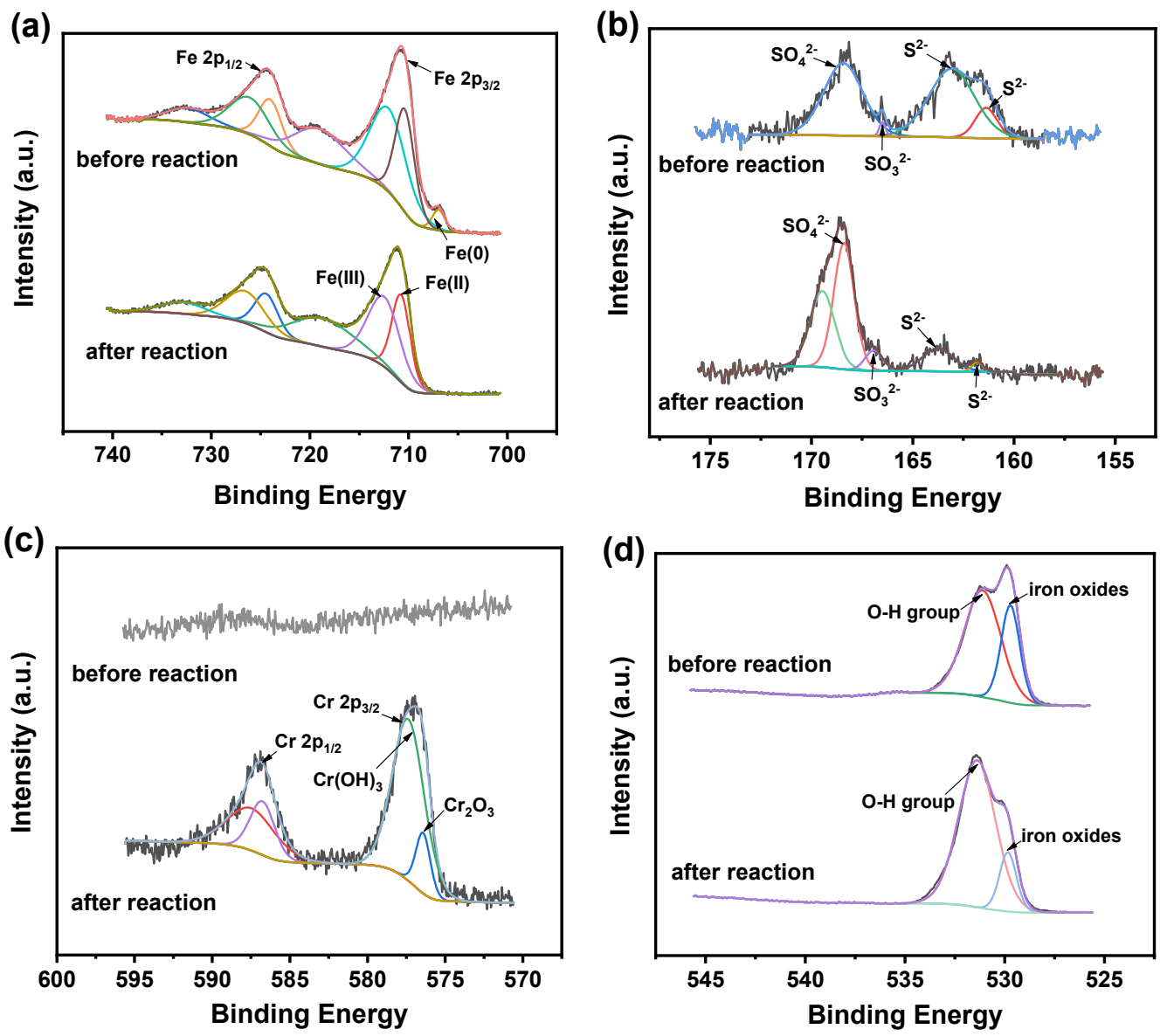

Figure 4. XPS spectra of (a) Fe 2p, (b) S 2p, (c) Cr 2p, (d) O 1 s of S-nZVI before and after the reaction.

In summary, a probable mechanism of BPA degradation and $\mathrm{Cr}(\mathrm{VI})$ removal by S$\mathrm{nZVI} / \mathrm{H}_{2} \mathrm{O}_{2}$ system was schematically elucidated, as shown in Figure 5. Under acidic conditions, $\mathrm{H}_{2} \mathrm{O}_{2}$ was activated by $\mathrm{Fe}^{2+}, \mathrm{Fe}^{3+}$ and $\mathrm{Fe}^{0}$ on the S-nZVI surface, producing - $\mathrm{OH}$ for BPA degradation. Interestingly, the co-existence of $\mathrm{Cr}(\mathrm{VI})$ negatively slowed the oxidation rate of BPA because of the competitive consumption of $\mathrm{H}_{2} \mathrm{O}_{2}$ and $\cdot \mathrm{OH}$. Conversely, the removal of $\mathrm{Cr}(\mathrm{VI})$ was positively promoted in the presence of BPA due to its oxidative reaction with $\cdot \mathrm{OH}$, which inhibited the reoxidation of $\mathrm{Cr}(\mathrm{III})$ by $\cdot \mathrm{OH}$. The stepwise removal of $\mathrm{Cr}(\mathrm{VI})$ involved reduction, re-oxidation, adsorption and immobilization. Initially, $\mathrm{Cr}(\mathrm{VI})$ was absorbed on the S-nZVI surface and occupied the reactive sites of S-nZVI, and then $\mathrm{Cr}(\mathrm{VI})$ was directly reduced to $\mathrm{Cr}$ (III) on the S-nZVI surface by $\mathrm{Fe}^{0}, \mathrm{Fe}(\mathrm{II})$ and $\mathrm{S}^{2-}$. The dissolved Fe(III) on the surface of S-nZVI could be reduced back to Fe(II) by $\mathrm{Fe}^{0}$ and $\mathrm{S}^{2-}$, giving rise to more ferrous sites for further $\mathrm{Cr}(\mathrm{VI})$ reduction. The produced $\mathrm{Cr}(\mathrm{III})$ and $\mathrm{Fe}$ (III) were present in the forms of mixed $\mathrm{Cr}$-Fe (oxy) hydroxides, and formed a passivation layer that impeded further reaction. However, it should be highlighted that not all $\mathrm{Cr}$ species could be captured by S-nZVI within the reaction time, and a considerable fraction of $\mathrm{Cr}(\mathrm{VI})$ was converted directly to $\mathrm{Cr}(\mathrm{III})$ through reaction with $\mathrm{H}_{2} \mathrm{O}_{2}$ under acidic conditions. 
The formed $\mathrm{Cr}(\mathrm{III})$ presented as dissolved ions at acidic $\mathrm{pH}$, but might sediment further in the form of chromium hydroxides.

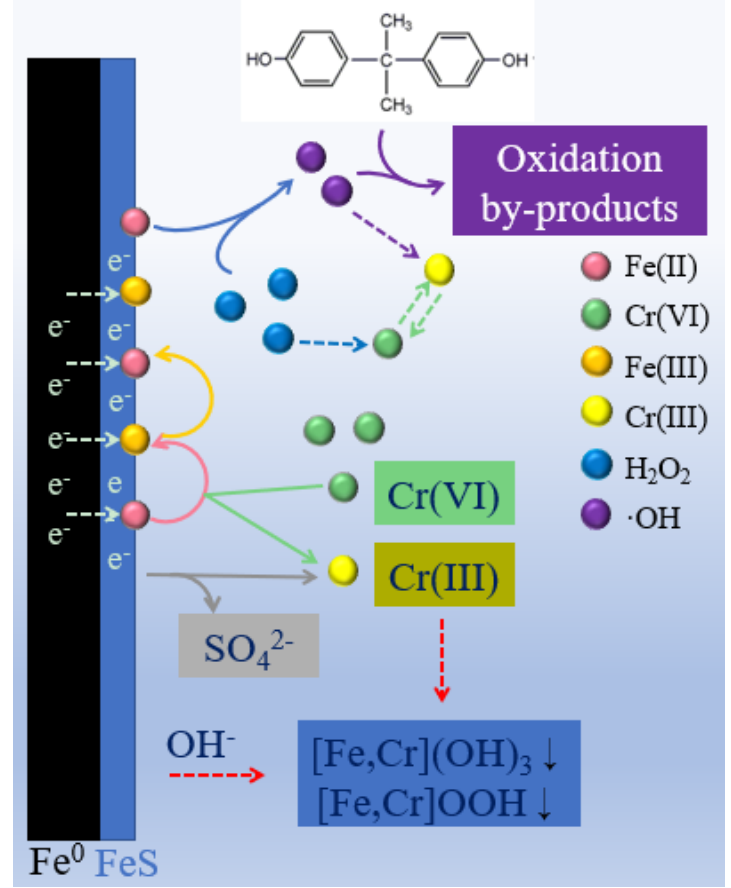

Figure 5. Schematic illustration of synchronous removal of BPA and $\mathrm{Cr}(\mathrm{VI})$ in the S-nZVI/ $\mathrm{H}_{2} \mathrm{O}_{2}$ system.

\section{Conclusions}

The present study used S-nZVI as a reductant and catalyst for heterogeneously activated $\mathrm{H}_{2} \mathrm{O}_{2}$ for the synchronous removal of $\mathrm{BPA}$ and $\mathrm{Cr}(\mathrm{VI})$ via processes including both degradation and reductive adsorption. The removal efficiency reached up to $98.2 \%$ for BPA and $96.9 \%$ for $\mathrm{Cr}(\mathrm{VI})$ within 60 min under optimum conditions, which were $\mathrm{pH} 3$, and concentrations of $0.05 \mathrm{~g} / \mathrm{L}$ of S-nZVI, and $0.2 \mathrm{mmol} / \mathrm{L}$ of $\mathrm{H}_{2} \mathrm{O}_{2}$, respectively. Compared to nZVI $/ \mathrm{H}_{2} \mathrm{O}_{2}$, the S-nZVI $/ \mathrm{H}_{2} \mathrm{O}_{2}$ Fenton-like system showed a very similar efficiency toward BPA degradation, but a faster rate for $\mathrm{Cr}(\mathrm{VI})$ removal. $\mathrm{HA}$ and $\mathrm{H}_{2} \mathrm{PO}_{4}{ }^{-}$inhibited, but $\mathrm{NO}_{3}{ }^{-}$promoted the degradation of BPA. This was different from BPA degradation in that the effects of water matrix on $\mathrm{Cr}(\mathrm{VI})$ removal were inconspicuous and $\mathrm{Cr}(\mathrm{VI})$ could be completely converted to $\mathrm{Cr}(\mathrm{III})$ after $30 \mathrm{~min}$ reaction time. In addition, $\cdot \mathrm{OH}$ was identified as the principal radical species in the S-nZVI/ $\mathrm{H}_{2} \mathrm{O}_{2}$ Fenton-like system for BPA degradation. However, the reaction with $\mathrm{Cr}(\mathrm{VI})$ was a complex process, involving not only reduction by both S-nZVI and $\mathrm{H}_{2} \mathrm{O}_{2}$, but also $\cdot \mathrm{OH}$-mediated oxidation of $\mathrm{Cr}(\mathrm{III})$. Additionally, the removal of $\mathrm{Cr}(\mathrm{VI})$ involved adsorption, reduction and immobilization on the S-nZVI surface, as further evidenced by XPS characterization. This study provides a new feasible solution for the treatment of complex polluted water bodies containing refractory organic pollutants and heavy metal pollutants.

Supplementary Materials: The following supporting information can be downloaded at: https: / / www.mdpi.com/article/10.3390/catal12030252/s1, Figure S1: Scanning electron micrograph of S-nZVI particles, (a) and (b) Scanning electron microscopy image of S-nZVI, (c) Spectral recording of a spot on S-nZVI image, Figure S2: TEM image of S-nZVI, Figure S3: XRD patterns of nZVI and S-nZVI, Figure S4: TOC removal efficiency in the S-nZVI/ $\mathrm{H}_{2} \mathrm{O}_{2} / \mathrm{Cr} / \mathrm{BPA}$ reaction system, Figure S5: Synchronous removal of (a) BPA and (b) $\mathrm{Cr}(\mathrm{VI})$ in systems of S-nZVI/ $\mathrm{H}_{2} \mathrm{O}_{2}$ and S-nZVI/PS, Figure S6: Effect of different conditions on simultaneous removal of BPA and $\mathrm{Cr}(\mathrm{VI})$ by S-nZVI; (a) and (b) solution $\mathrm{pH}$; (c) and (d) oxidant dosage; (e) and (f) catalyst dosage, Figure S7: EPR characterization using DMPO, Figure S8: Reusability of S-nZVI for synchronous removal of $\mathrm{Cr}(\mathrm{VI})$ and BPA in the S-nZVI $/ \mathrm{H}_{2} \mathrm{O}_{2} / \mathrm{Cr} / \mathrm{BPA}$ reaction system, Figure S9: XRD patterns of S-nZVI before and after the 
reaction in the S-nZVI/ $\mathrm{H}_{2} \mathrm{O}_{2} / \mathrm{Cr} / \mathrm{BPA}$ system, Figure S10: XPS spectra of C 1s of S-nZVI before and after the reaction, Table S1: The atomic fraction of each element of S-nZVI before and after the reaction.

Author Contributions: H.L.: Experiments and manuscript organization. X.Z.: Experiments and manuscript writing. T.Z.: Experiments and manuscript writing. F.S.: Experiments. J.B.: Manuscript structure guidance. J.D.: Guidance, review, and editing. All authors have read and agreed to the published version of the manuscript.

Funding: The research was conducted under the support from National Natural Science Foundation of China (41907153), National Key Research and Development Program of China (2019YFC1804004).

Data Availability Statement: Data is contained within the article or Supplementary Material.

Conflicts of Interest: There are no conflicts of interest to declare.

\section{References}

1. Barrera-Díaz, C.E.; Lugo-Lugo, V.; Bilyeu, B. A review of chemical, electrochemical and biological methods for aqueous Cr(VI) reduction. J. Hazard. Mater. 2012, 223-224, 1-12. [CrossRef] [PubMed]

2. Zhao, G.; Sun, Y.; Zhao, Y.; Wen, T.; Wang, X.; Chen, Z.; Sheng, G.; Chen, C.; Wang, X. Enhanced Photocatalytic Simultaneous Removals of $\mathrm{Cr}(\mathrm{VI})$ and Bisphenol A over Co(II)-Modified $\mathrm{TiO}_{2}$. Langmuir 2019, 35, 276-283. [CrossRef]

3. Dong, F.-X.; Yan, L.; Zhou, X.-H.; Huang, S.-T.; Liang, J.-Y.; Zhang, W.-X.; Guo, Z.-W.; Guo, P.-R.; Qian, W.; Kong, L.-J.; et al. Simultaneous adsorption of $\mathrm{Cr}(\mathrm{VI})$ and phenol by biochar-based iron oxide composites in water: Performance, kinetics and mechanism. J. Hazard. Mater. 2021, 416, 125930. [CrossRef] [PubMed]

4. Zou, H.; Hu, E.; Yang, S.; Gong, L.; He, F. Chromium(VI) removal by mechanochemically sulfidated zero valent iron and its effect on dechlorination of trichloroethene as a co-contaminant. Sci. Total Environ. 2019, 650, 419-426. [CrossRef]

5. Neyens, E.; Baeyens, J. A review of classic Fenton's peroxidation as an advanced oxidation technique. J. Hazard. Mater. 2003, 98, 33-50. [CrossRef]

6. Fang, Y.; Yin, W.; Jiang, Y.; Ge, H.; Li, P.; Wu, J. Depth treatment of coal-chemical engineering wastewater by a cost-effective sequential heterogeneous Fenton and biodegradation process. Environ. Sci. Pollut. Res. 2018, 25, 13118-13126. [CrossRef]

7. Babuponnusami, A.; Muthukumar, K. A review on Fenton and improvements to the Fenton process for wastewater treatment. J. Environ. Chem. Eng. 2014, 2, 557-572. [CrossRef]

8. Tang, W.Z.; Chen, R.Z. Decolorization kinetics and mechanisms of commercial dyes by $\mathrm{H}_{2} \mathrm{O}_{2}$ /iron powder system. Chemosphere 1996, 32, 947-958. [CrossRef]

9. Martins, R.C.; Lopes, D.V.; Quina, M.J.; Quinta-Ferreira, R.M. Treatment improvement of urban landfill leachates by Fenton-like process using ZVI. Chem. Eng. J. 2012, 192, 219-225. [CrossRef]

10. Minella, M.; Sappa, E.; Hanna, K.; Barsotti, F.; Maurino, V.; Minero, C.; Vione, D. Considerable Fenton and photo-Fenton reactivity of passivated zero-valent iron. RSC Adv. 2016, 6, 86752-86761. [CrossRef]

11. Fu, F.; Dionysiou, D.D.; Liu, H. The use of zero-valent iron for groundwater remediation and wastewater treatment: A review. J. Hazard. Mater. 2014, 267, 194-205. [CrossRef]

12. Diao, Z.-H.; Xu, X.-R.; Jiang, D.; Liu, J.-J.; Kong, L.-J.; Li, G.; Zuo, L.-Z.; Wu, Q.-H. Simultaneous photocatalytic Cr(VI) reduction and ciprofloxacin oxidation over $\mathrm{TiO}_{2} / \mathrm{Fe}^{0}$ composite under aerobic conditions: Performance, durability, pathway and mechanism. Chem. Eng. J. 2017, 315, 167-176. [CrossRef]

13. Yin, X.; Liu, W.; Ni, J. Removal of coexisting $\mathrm{Cr}(\mathrm{VI})$ and 4-chlorophenol through reduction and Fenton reaction in a single system. Chem. Eng. J. 2014, 248, 89-97. [CrossRef]

14. Yang, B.; Zhou, P.; Cheng, X.; Li, H.; Huo, X.; Zhang, Y. Simultaneous removal of methylene blue and total dissolved copper in zero-valent iron $/ \mathrm{H}_{2} \mathrm{O}_{2}$ Fenton system: Kinetics, mechanism and degradation pathway. J. Colloid Interface Sci. 2019, 555, 383-393. [CrossRef]

15. Diao, Z.-H.; Xu, X.-R.; Chen, H.; Jiang, D.; Yang, Y.-X.; Kong, L.-J.; Sun, Y.-X.; Hu, Y.-X.; Hao, Q.-W.; Liu, L. Simultaneous removal of $\mathrm{Cr}(\mathrm{VI})$ and phenol by persulfate activated with bentonite-supported nanoscale zero-valent iron: Reactivity and mechanism. $J$. Hazard. Mater. 2016, 316, 186-193. [CrossRef] [PubMed]

16. Diao, Z.-H.; Xu, X.-R.; Jiang, D.; Kong, L.-J.; Sun, Y.-X.; Hu, Y.-X.; Hao, Q.-W.; Chen, H. Bentonite-supported nanoscale zero-valent iron/persulfate system for the simultaneous removal of $\mathrm{Cr}(\mathrm{VI})$ and phenol from aqueous solutions. Chem. Eng. J. 2016, 302, 213-222. [CrossRef]

17. Du, J.; Bao, J.; Lu, C.; Werner, D. Reductive sequestration of chromate by hierarchical FeS@Fe0 particles. Water Res. 2016, 102, 73-81. [CrossRef]

18. Fontmorin, J.M.; Castillo, R.C.B.; Tang, W.Z.; Sillanpaa, M. Stability of 5,5-dimethyl-1-pyrroline-N-oxide as a spin-trap for quantification of hydroxyl radicals in processes based on Fenton reaction. Water Res. 2016, 99, 24-32. [CrossRef] [PubMed]

19. Du, J.; Bao, J.; Fu, X.; Lu, C.; Kim, S.H. Mesoporous sulfur-modified iron oxide as an effective Fenton-like catalyst for degradation of bisphenol A. Appl. Catal. B Environ. 2016, 184, 132-141. [CrossRef] 
20. Liu, C.-M.; Diao, Z.-H.; Huo, W.-Y.; Kong, L.-J.; Du, J.-J. Simultaneous removal of $\mathrm{Cu}^{2+}$ and bisphenol A by a novel biocharsupported zero valent iron from aqueous solution: Synthesis, reactivity and mechanism. Environ. Pollut. 2018, 239, 698-705. [CrossRef]

21. Dehghani, M.H.; Heibati, B.; Asadi, A.; Tyagi, I.; Agarwal, S.; Gupta, V.K. Reduction of noxious Cr(VI) ion to Cr(III) ion in aqueous solutions using $\mathrm{H}_{2} \mathrm{O}_{2}$ and $\mathrm{UV} / \mathrm{H}_{2} \mathrm{O}_{2}$ systems. J. Ind. Eng. Chem. 2016, 33, 197-200. [CrossRef]

22. Gheju, M.; Iovi, A. Kinetics of hexavalent chromium reduction by scrap iron. J. Hazard. Mater. 2006, 135, 66-73. [CrossRef] [PubMed]

23. Woo, Y.S.; Rafatullah, M.; Al-Karkhi, A.F.M.; Tow, T.T. Removal of Terasil Red R dye by using Fenton oxidation: A statistical analysis. Desalin. Water Treat. 2014, 52, 4583-4591. [CrossRef]

24. Guo, S.; Yang, W.; You, L.; Li, J.; Chen, J.; Zhou, K. Simultaneous reduction of Cr(VI) and degradation of tetracycline hydrochloride by a novel iron-modified rectorite composite through heterogeneous photo-Fenton processes. Chem. Eng. J. 2020, $393,124758$. [CrossRef]

25. Abdul, N.A.; Abdul-Talib, S.; Amir, A. Nano-pyrite as a Reductant to Remove Chromium in Groundwater. KSCE J. Civ. Eng. 2019, 23, 992-999. [CrossRef]

26. Rehman, F.; Sayed, M.; Khan, J.A.; Shah, N.S.; Khan, H.M.; Dionysiou, D.D. Oxidative removal of brilliant green by UV/S $\mathrm{O}_{8}{ }^{2-}$ $\mathrm{UV} / \mathrm{HSO}_{5}{ }^{-}$and $\mathrm{UV} / \mathrm{H}_{2} \mathrm{O}_{2}$ processes in aqueous media: A comparative study. J. Hazard. Mater. 2018, 357, 506-514. [CrossRef]

27. Mak, M.S.H.; Rao, P.; Lo, I.M.C. Effects of hardness and alkalinity on the removal of arsenic(V) from humic acid-deficient and humic acid-rich groundwater by zero-valent iron. Water Res. 2009, 43, 4296-4304. [CrossRef]

28. Lv, X.; Hu, Y.; Tang, J.; Sheng, T.; Jiang, G.; Xu, X. Effects of co-existing ions and natural organic matter on removal of chromium (VI) from aqueous solution by nanoscale zero valent iron (nZVI)-Fe ${ }_{3} \mathrm{O}_{4}$ nanocomposites. Chem. Eng. J. 2013, 218, 55-64. [CrossRef]

29. Zhang, R.; Sun, H.; Yin, J. Arsenic and chromate removal from water by iron chips-Effects of anions. Front. Environ. Sci. Eng. China 2008, 2, 203-208. [CrossRef]

30. Ma, J.; Yang, Y.; Jiang, X.; Xie, Z.; Li, X.; Chen, C.; Chen, H. Impacts of inorganic anions and natural organic matter on thermally activated persulfate oxidation of BTEX in water. Chemosphere 2018, 190, 296-306. [CrossRef]

31. Døssing, L.N.; Dideriksen, K.; Stipp, S.L.S.; Frei, R. Reduction of hexavalent chromium by ferrous iron: A process of chromium isotope fractionation and its relevance to natural environments. Chem. Geol. 2011, 285, 157-166. [CrossRef]

32. Funahashi, S.; Uchida, F.; Tanaka, M. Reactions of hydrogen peroxide with metal complexes. 3. Thermodynamic and kinetic studies on the formation, dissociation and decomposition of peroxochromium(VI) complexes in acid media. Inorg. Chem. 1978, 17, 2784-2789. [CrossRef]

33. Watwe, V.S.; Kulkarni, S.D.; Kulkarni, P.S. Cr(VI)-Mediated Homogeneous Fenton Oxidation for Decolorization of Methylene Blue Dye: Sludge Free and Pertinent to a Wide pH Range. ACS Omega 2021, 6, 27288-27296. [CrossRef] [PubMed]

34. Gong, Y.; Gai, L.; Tang, J.; Fu, J.; Wang, Q.; Zeng, E.Y. Reduction of Cr(VI) in simulated groundwater by FeS-coated iron magnetic nanoparticles. Sci. Total Environ. 2017, 595, 743-751. [CrossRef]

35. Song, X.; Ren, C.; Zhao, Q.; $\mathrm{Su}, \mathrm{B}$. Simultaneous removal of $\mathrm{Cr}(\mathrm{VI})$ and triclosan from aqueous solutions through $\mathrm{Fe}_{3} \mathrm{O}_{4}$ magnetic nanoscale-activated persulfate oxidation. Chem. Eng. J. 2020, 381, 122586. [CrossRef]

36. Sun, Y.-P.; Li, X.-Q.; Cao, J.; Zhang, W.-X.; Wang, H.P. Characterization of zero-valent iron nanoparticles. Adv. Colloid Interface Sci. 2006, 120, 47-56. [CrossRef]

37. Jeong, H.Y.; Han, Y.-S.; Park, S.W.; Hayes, K.F. Aerobic oxidation of mackinawite (FeS) and its environmental implication for arsenic mobilization. Geochim. Cosmochim. Acta 2010, 74, 3182-3198. [CrossRef]

38. Rajajayavel, S.R.C.; Ghoshal, S. Enhanced reductive dechlorination of trichloroethylene by sulfidated nanoscale zerovalent iron. Water Res. 2015, 78, 144-153. [CrossRef]

39. Pratt, A.R.; Muir, I.J.; Nesbitt, H.W. X-ray photoelectron and Auger electron spectroscopic studies of pyrrhotite and mechanism of air oxidation. Geochim. Cosmochim. Acta 1994, 58, 827-841. [CrossRef]

40. Zhu, X.; Le, T.T.; Du, J.; Xu, T.; Cui, Y.; Ling, H.; Kim, S.H. Novel core-shell sulfidated nano-Fe(0) particles for chromate sequestration: Promoted electron transfer and Fe(II) production. Chemosphere 2021, 284, 131379. [CrossRef] [PubMed]

41. Biesinger, M.C.; Lau, L.W.M.; Gerson, A.R.; Smart, R.S.C. Resolving surface chemical states in XPS analysis of first row transition metals, oxides and hydroxides: Sc, Ti, V, Cu and Zn. Appl. Surf. Sci. 2010, 257, 887-898. [CrossRef] 